\title{
The Use of the Sava River as an International Allocation Problem
}

Helmut Braun*

\begin{abstract}
The use of trans-national common resources like rivers often creates problems between countries, but can also, as some historical examples show, give possibilities for stronger, friendlier political relations. The core of the solution to common resources is precise regulation through trans-national agreements that can be changed only in a Paretian manner. After a short presentation of examples of such agreements, the process of decision-making implemented in the 2004 Sava Framework Agreement will be analysed using economic theory, especially the Coase theorem and simple bargaining theory. Property rights in this agreement seem to be weak, as well as some regulations of the decision process itself. This weakness can be cured by installing a supra-national authority to supervise the decision-making process. In this case, the authority would be the European Union, as all the countries involved are trying to harmonise with the EU.
\end{abstract}

JEL: 052, P48, Q58, Z00

DOI: 10.2478/v10033-008-0005-9

\section{Outline of the Problem and Historical Overview}

The use of trans-national common resources has always been a source of problems between countries. Rivers and waterways demarcating national borders especially often cause problems in regard to their utilisation: clean, fresh water is essential for biological systems, and fresh water scarcity has been a cause for conflict between people throughout recorded history. Whenever the same interests in utilisation collide, e.g. exploiting natural resources like fish, people are more likely to find a solution because they are interested in exploiting these resources. The littoral states at the source of the course of the river always have the advantage of being the first to exploit these resources, which can also lead to tensions. If interests in its utilisation compete with each other, such as fishing and pollution, then conflicts will arise, like emissions leaked into a river that make fishing dangerous

* The author is indebted to Prof. Dr. Meho Bašić and to Prof Dr. Štefan Bojnec for helpful comments on the first draft of the paper presented in session K, ICES 2006 and to two anonymous referees who made valuable comments. by harming human health, or when fish stocks disappear because of pollution.

On the one hand, therefore, trans-boundary waterways can create political tensions: Israeli-Jordanian conflicts over withdrawals from the Jordan River were a major cause of the Arab-Israeli War in 1967, and water still remains today a source of tension between nations in the Middle East, Africa and Asia, as the example of the pollution of the Amur river shows (Issar and Brown, 2004; OCHA Situation Report No. 2). On the other hand, however, the use of common resources such as rivers can promote peace between the countries involved if an appropriate problem-solving institutional mechanism
*Braun:
University of Regensburg, Faculty of Economics,
Universitäts-Strasse 31,
D-93040 Regensburg, Germany
e-mail: helmut.braun@wiwi.uni-regensburg.de 
will be or has been instituted. Such cooperation reveals an important connection between conflict prevention regarding natural resources and confidence-building in general. Environmental co-operation between two or more states often leads to cooperation on more complicated issues. For example, in 1998 a "park of peace" between Ecuador and Peru was an element in solving their territorial dispute (UNEP).

The Sava River, originating in Slovenia, is an important border in the northern part of Bosnia and Herzegovina to Croatia and Serbia (Holbrooke, 1998, pp. 272-273). In the past, the Sava River sometimes was a source of conflicts and tensions. Nowadays, no one disputes this natural borderline anymore and the Sava River has only relatively small problems with competing utilities, especially navigation, which normally does no harm to the quality and quantity of water, the production of drinking-water, fishing, and exploitation of gravel. Crossbordering pollution by waste-deposits exists on a normal level. To resolve these problems various international agreements have been made in the past. Therefore, we will first show the development and structure of some important agreements.

To tackle our "peace-promoting idea", we present the economic characteristics of common resources, discuss the role of the Coase-Theorem and introduce and analyse the Game-Theoretical Approach. We then demonstrate how the allocation problem was solved in the past, using a few important examples. After this, we have a closer look at the Framework Agreement on the Sava River Basin. Finally, we give a conclusion with an assessment of the solution of the Save Framework Agreement as a too for I promoting peace between the states involved indirectly.

\section{Some Examples of International Agreements Concerning Trans-boundary Rivers}

The Convention regarding the Regime of Navigation on the Danube signed in 1948 is the international legal instrument governing navigation on the Danube. The socalled "Belgrade Convention" provides for free navigation on the Danube in accordance with the interests of the parties while strengthening the economic relations between themselves and with other nations. According to the Convention, eleven member states ${ }^{1}$ are responsible for maintaining their sections of the Danube in a navigable condition for river-going and, in the appropriate sections, to not hinder the navigation of sea-going vessels on the navigable channels of the Danube. The Danube Commission, which consists of one representative from each of the member states, was established to supervise the implementation of the 1948 Convention and to fulfil various other tasks aimed at ensuring adequate conditions

\footnotetext{
1 These states are Austria, Bulgaria, Croatia, Germany, Hungary, Moldova, Slovakia,
} Romania, Russia, Ukraine, Serbia and Montenegro. for shipping on the Danube. Historically speaking, its basis dates back to the Paris Conferences of 1856 and 1921, which established an international regime to safeguard free navigation on the Danube for the first time. Another relevant question in this context is the harmonisation of technical prescriptions, rules and standards in force on the Danube and the Rhine within the European Union, and those adopted by the United Nations' Economic Commission for Europe (ECE UNO), with the aim of creating a uniform Pan-European system of inland navigation.

With this cooperation, special attention is given to constantly improving technical and legal conditions of navigation for the vessels of all nations. Environmental issues are not mentioned at all in the Convention regarding the Regime of Navigation on the Danube (http://www. danubecom-intern.org). As navigation is only one kind of the utilisation of the common resource of a "river", other fields of conflict remain unsolved, especially any problems from pollution. The river Danube was used peacefully because the convention worked.

The Helsinki Rules cover different utilisation than that addressed by the Danube Convention. Adopted by the International Law Association at the fifty-second conference held at Helsinki in August 1966, the "Helsinki Convention" for the prevention and use of trans-boundary water courses and international Lakes obliges parties to prevent, control and reduce water pollution. Equitable utilisation, as it had been known in international water law, was defined in Article 4, which provides that a basin state is entitled to an equitable and reasonable share of the beneficial uses of the waters of an international drainage basin. It was recognised that a basin state has a right, not to an equal share of the waters of the basin, but to beneficially use those waters (UNESCO, p. 302). Now, the specific problems of the allocation of the common resource of a trans-boundary river have already been discussed. The Helsinki Rules also include provisions for monitoring, research and development, consultations, alarm systems, mutual assistance, information exchange and public access to information concerning waterways (http://www.internationalwaterlaw.org).

The main international legal document related to international water resources management is the UN Convention on the Law of the Non-navigational Uses of International Water Courses (1997). This Agreement has an authoritative function and covers more issues than any agreements made before. Above all, it indicates a broad agreement among states on the general principles relating to equitable and reasonable resource use, the duty not to cause significant harm, ecosystem protection, management obligations, information sharing, conflict resolution and the protection of the resource during armed conflicts (http://untreaty.un.org/ilc/texts/instruments/ english/conventions/8_3_1997.pdf). 
The Rhine is an important European river with diverse uses, including navigation. Therefore, it is exposed to many hazards. The River Rhine also forms an important ecosystem worthy of protection. Since 1950, the countries along the Rhine have cooperated under the roof of the ICPR to jointly protect the Rhine. ICPR work deals with water quality and emissions, ecology and floods. In addition, all countries bordering the Rhine are united in the Coordinating Committee Rhine. This body deals with co-ordinating the implementation of the European Water Framework Directive. Its basic target is the restoration of the good state of the Rhine and its water within the watershed in a peaceful way between the nations bordering the river Rhine (http://www.iksr.org/index.php?id=295).

These examples give two lessons. The protection of the environment was a goal -or an allocation problemwhich was recognized late. The regularities of any common use of the river Danube as well as the Rhine were realized after World War II, when (Western) Europe had to be prepared for unification. In other words, various foreign events promoted a peaceful and wealthproducing cooperation on the use of the common resource of both rivers.

\section{The Problem of Trans-boundary Common Resources: Some Theoretical Considerations}

\subsection{Traditional Theory of Common Resources and Property Rights}

In order to preserve a natural environment and to prevent catastrophes like floods or hazardous pollution, preventive measures have to be taken and coordinated. With trans-national common resources such as river basins, co-ordination problems between nations arise from the issue of full open access for all parties to the river. In this case, individuals will overexploit common resources as private benefits exceed private costs. For this reason, these public goods are called "non-excludable", and "non-rivalry" in consumerism, which create problems for market-allocation. First, transaction costs do exist, which entails costs for getting information concerning "prices" of common goods and the costs of bargaining and finding an efficient solution. Second, free-riding-phenomena and the production of externalities occur. This means factual, nonmarket transaction compensated pollution in a certain area to an amorphous mass of "victims". Every polluter will benefit from this action, weather he stops his polluting or not, or whether he will be paid for stopping pollution or not. The higher the number of "victims," the more difficult it will be to avoid free-riding in the rivalry of consumerism. Every "victim" has to suffer from pollution, and every single "victim" has no rational possibility to pay the polluter(s) any sum of money to give him an incentive to stop pollution.
Pollution, therefore, is a common good for all polluters and a common "bad" for all "victims." This is a consequence of incomplete property-rights, which leads to inefficient allocations if one individual user appropriates the common good factually and prevents others completely from using it by, for example, polluting a river in a manner that excludes all others from using the water of the river for drinking or fishing. The two uses mentioned rival one another because of incomplete property rights regarding "clean water" and "water as a deposit of waste"; the public good problem shows why it is impossible to make people pay for clean environment, and why free-riding is a rational reaction. The forces of a free market do not provide the correct economic incentives to save the environment, especially when property-rights are not exactly defined and therefore are not achieved by law (Demsetz, 1964, 1967; Alchian 1977, Posner 1977, Barzel, 1985; Hoppe 1989; Goodstein, 2005, pp. 34-39). In this case, new and exclusive property rights had to be defined by an authority. These property rights had to define any possibility of use, liability, and compensation rules.

The definition of use regarding the common resource of a river, however, is a problem of intermediating between a small number of sovereign parties that are able to hinder any common solution by each of the parties involved. Therefore, these parties play an allocation game with an unknown result concerning a Paretian situation. ${ }^{2}$

In 1960, Ronald Coase showed that every precise definition of property-rights leads to an efficient internalisation of external effects, assuming that the participants have perfect information and the type of bargaining is specified. This result is valid, regardless of to whom the property-rights belong, the "polluter" or the "victim". This also means that the traditional "polluter pays principle" is outdated; the structure of the problem is a reciprocal one (Coase, 1960). External costs are not simply costs produced by a polluter and tolerated by a victim. In most cases they are the result of decisions made by both parties. For example, the victim decided to stay near the factory that pollutes the air or, in another case, a factory-owner decided to build a new factory in the neighbourhood of the victim. Hence, externalities are the joint product of a polluter and a victim, and every governmental regulation that lays the blame on one party will lead to an efficient result only if that party is the one able to avoid the problem at a lower cost. The regulator - in most cases the government - can only guarantee the efficient outcome if it has enough information about the cost of pollution-control (Robson and Skaperdas, 2001, p.2). As long as the parties involved are able to make and enforce contracts in their mutual interest, neither direct

2 In the case of the River Sava, the problem of trans-national common resources is not only the problem of pollution by emissions, but also the navigation on the Sava River, as it is also used for shipping. The common use of a river for shipping, however, was an international problem that was solved in general very early. In these times, however, any environmental problems were not recognised as relevant problems. 
regulation nor taxes are necessary to obtain an efficient outcome. The only essential precondition is the clear definition of property rights: who has a right to pollute and who has a right to an unpolluted environment. If this is this assumed, and transaction costs are zero, the market will lead to an efficient allocation (Coase, 1960). In other words, any agreement that is to the mutual benefit of all of the parties concerned leads to an efficient outcome. Who, however, defines effective property rights?

The establishment of clear and strong propertyrights is a precondition for successful internalisation by bargaining. In the case of the Sava River, however, property rights are defined in a very abstract manner and hence the prerequisite is only weakly met. Does this provide the chance to finally come to an efficient allocation if problems about use occur?

In regard to the Framework Agreement of the Sava River Basin, the parties can make changes concerning different utilisation, e.g. fishing, fresh water, etc. The precondition for a change is a "consensus," which means that only if there is uniform agreement will a measure be taken. Understandably, it may be difficult to work out such an agreement; the more parties involved, the more difficult it will be to reach a consensus. In case one single party suffers a loss by a new measure, e.g. their territory is polluted by emissions, then a rationally acting individual will not agree to take the measure. Yet the other members have the capacity to persuade the individual - in our case a country - by making up for the loss. Therefore, the parties have to bargain over the compensation.

The parties that want to make the modifications to the agreement, let us say parties 2 and 3, can make an offer to party 1 - the one with the loss. If the offer is high enough, or at least as high as the loss of party 1 , then party 1 may agree. But then a few problems arise. If the compensation payment offered by parties 2 and 3 equal the loss of party 1 , then there is no real incentive for party 1 to agree. Thus, the other parties have to raise the offer. In case party 1 estimates the profit of the other parties correctly it can demand more. It can demand as much as the whole gains of parties 2 and 3 . If it demands more, no solution will be found, since parties 2 and 3 have no incentive to agree because they will suffer net losses from such a high compensation payment. For this reason, the compensation payment will amount to a sum between the loss of party 1 and the profits of parties 2 and 3 . However, if transaction costs are not zero, these costs reduce the volume of the sum of the compensation that can be offered. To finally find a solution for the allocation problem, or to change the Sava Framework Agreement itself, the new solution or change has to include an improvement for all of the members. This also means that in case one member is put at a disadvantage by a possible new measure, it is necessary for the others to make up for the disadvantage or loss of the other member. Only by doing this will a consensus be reached. The parties of the Framework Agreement have to bargain in order to find a consensus. In the real world, however, bargaining between two or more parties is not without transaction costs. Can a strong authority on a decision-level above the parties provide a cost-reducing solution that allows bargaining with little or none of these costs?

If the loss of one member is higher than the profit of the other parties, the solution is not efficient and the parties will not ratify such a treaty. Finally, a solution will only be found and implemented if there is an improvement in sum - i.e., all of the members benefit. In economic terms, only if an allocation is more efficient than the previous allocation can the measure that leads to this allocation be taken. The term "consensus" only "allows" improvements, or at least no deterioration. The same can be observed on the "commission level." Only a better allocation, or at least no worse allocation will be implemented. For this reason, this additional level of decision-making seems be considered obsolete. However, a justification for such a commission can be that experts on the Sava River will be chosen who know the facts and are therefore able to come to an agreement more quickly. These experts can realise lower transaction costs.

In order to lead to an efficient allocation, information is necessary. In this case it is assumed that information is distributed symmetrically among the parties involved; the prerequisites of this "system" are that a profit or loss can be reliably estimated. Only if the parties concerned know exactly about the losses and profits of a measure will they be able to make the right decision. Consequently, an exact analysis of risks and potential profits has to be made to show whether a measure is efficient or not. If the parties involved are not able or unwilling to estimate risks and profits exactly, the next decision-level has to take over this task. This decision-level also plays an important role if the bargaining processes are guided by "strategic" lines of discussions, e.g. in regard to the estimation of a "fair" sum of compensation.

\subsection{Game-Theoretical Approach: The Prisoner's Dilemma and the Role of an Authority}

Before analysing the situation of the use of the Sava River, we first have to show the attributes of the special situation of this trans-boundary "problem," as the attributes of the common resource of a "river" are complex: On the one hand, there are ways of utilising the river, such as navigation, that hardly compete with others, e.g. fishing. On the other hand, the river might be used to get rid of waste or other emissions, which competes with other forms of utilisation such as fishing or extracting drinking water. Hence, the common resource of a "river" 
is not clearly a complementary or competing resource. It depends on how the river is used. Furthermore, the attributes "non-rivalry" or "rivalry" depend on who is the first to use the river. In general, everyone can use a river for drinking water, fishing, etc. Yet if the user at the beginning of the course of a river pollutes the river, those that come after will not be able to use the water in the way they intended. For this reason, rivalry in the use of the common resource of a "river" will emerge that will cause problems between the parties concerned.

The attributes of the individuals in this case are clearer: three states with a homogenous structure concerning preferences and utilities, making it easier for them to cooperate. Furthermore, there is an authority, the European Union, which is able to settle disputes, and which is anticipated by the three parties of the Sava Framework Agreement. This authority is able to sanction by general political interventions the non-cooperative behaviour of the three parties in their bargaining. The possibility of mutual sanctions, the possibility of political sanctions by the European Union as an authority, and the possibility of communication facilitate the resolution of conflicts (Holzinger, 2003).

\section{The Sava River Basin Agreement}

\subsection{General Purpose}

After the first important meeting regarding the Sava river in November 2001, with Serbia and Montenegro as the participating party and a signatory to the Letter of Intent concerning the International Sava Basin Commission, in December 2004 the Framework Agreement of the Sava River Basin was signed by Bosnia and Herzegovina, the Republic of Croatia and the Republic of Slovenia and came into effect. (http://www.rec.org/REC/Programs/sava/pdf/ BackgroundPaper.pdf) The countries agreed to cooperate in a constructive and mutually beneficial manner for: (1) establishing navigation as specified in the 1948 Convention on the Regime on the Navigation on the Danube, international conventions regarding inland navigation, and the resolutions of ECE UNO, and together with the Republic of Slovenia for (2) promoting sustainable development of the Sava Basin by regulating utilisation, protection and management of the Sava Basin water and related natural resources (http://www.stabilitypact.org; http://www.rec.org/REC/Programs/sava/pdf).

It contains the goals of establishing an international regime of navigation, sustainable water management, and undertaking measures to prevent or limit hazards, and reduce and eliminate adverse consequences, including those related to floods, ice hazards, droughts and incidents involving substances hazardous to water (Framework Agreement of the Sava River Basin, p. 2). The Agreement recognises the importance of trans-boundary cooperation towards navigation, water management and sustainable development.

\subsection{Decision Making on the First Decision Level}

Any change to the Sava River Basin Agreement, as well as termination of the agreement, has to be made by consensus. This means that only if every country ${ }^{3}$ agrees can modifications be made. The consequence of this fact is that a country will only agree if it gains an advantage with the change, or will at least not be at a disadvantage. Finally, changes to the agreement will only be made if there is an improvement for one member.

If another member suffers a loss from a potential modification of the agreement, it will be possible for the other(s) to compensate for the loss, e.g. by payment. But this will only be done if the gains are high enough to make up for the loss. Therefore, the change always has to imply a net improvement for the members/ countries as a whole; otherwise any compensation high enough to make the one member/country agree will not be paid.

\subsection{The Second Decision Level - Same Provision}

The Framework Agreement on the Sava River Basin includes a second level, the so-called "Sava Commission" that also will make decisions, (1) aimed to provide conditions for safe navigation; (2) on the conditions for financing construction of navigable waterways and their maintenance; (3) on its own work, budget and procedures. This commission is established and financed by the parties; it has the function of representing each party equally.

The problem is, if no consensus concerning a modification on the agreement is found by the parties, a consensus will hardly be found by the Sava Commission, because the representative of any party will not make a decision that includes more disadvantages than advantages for his party. The "problem" of finding an agreement is only postponed to another level but with the same provisions. Only if there is an improvement for each party, or at least no deterioration, will a decision for a change be made. The advantage of such a commission can only be that it contains experts concerning the issues mentioned above. These experts will be able to find solutions and come to an agreement much more efficiently, in other words more quickly, than the parties themselves.

3 The words "countries", "parties", and "members" are used synonymously in this context. 


\subsection{Dispute Settlement}

If the three parties, Bosnia and Herzegovina, the Republic of Croatia and the Republic of Slovenia, are unable to resolve disputes through negotiation, any party concerned can request that an independent "fact-finding expert committee" be established (http://www.rec.org/REC/Programs/sava/ pdf/BackgroundPaper.pdf). This committee consists of three experts, with each party appointing one. The experts select another expert who is not a citizen of the concerned parties and who has the function of a chairman of the expert committee. If the nominated members of the committee are unable to decide on the selection of a chairman, the President of the International Court of Justice can nominate a chairman, who may not be a citizen of any of the countries concerned. The countries concerned are obliged, upon the request of the committee, to provide all information regarding the dispute and to permit the committee to enter their territories and inspect locations, installations and equipment necessary for its work. The experts should be provided with the necessary information in order to know the necessary facts to find an efficient solution. The committee adopts by majority vote the report of its findings. If the report is not adopted by unanimous vote, a dissenting opinion may be submitted that will be included in the report.

Now we will try to summarize the merits and deficits of this agreement, both economically and politically, as a basis for an efficient solution.

\section{Conclusion}

The aspects discussed can be interpreted as a substitute for weak property rights by strong political interests who define, as strong property rights, the limits of "efficient" bargaining. Additionally, a strong authority like the European Union preserves the "peaceful rules of the game" in the bargaining process between the parties in conflict.

The classic"model" of the prisoner's dilemma demonstrates that if preventive measures against pollution should be taken there will hardly be an efficient solution by weak property rights without the intervention of an authority, e.g. an organisation or government, because every party wants to get a "free-ride." In the case of the Sava River Basin, the European Union could act as such an authority. If a dispute without any solution exists on the level of the parties, the European Union as an authority on a higher level will be able to settle the dispute. Each of the three parties involved in the Sava Framework Agreement are interested in friendship with and potential membership in the European Union.

The intention to stay on friendly terms with the members of the European Union may also work as an incentive for the parties to settle their dispute "efficiently" under the political constraint given by EU authority. This special constellation makes a sustainable cooperation easier and more probable.

The Framework Agreement of the Sava River Basin is the first and fundamental step for cooperation regarding the use of the common resource of a "river". In this case, decision-making in regard of any trans-boundary problem is regulated as well as possible, albeit in a very abstract manner. The Framework Agreement of the Sava River Basin does not define exact property rights in a clear juridical manner as was demanded by Coase: it remains unclear which party, i.e. firms in any of the countries involved, has a right to pollute in a predefined quantity, and which party has the right to demand compensation.

The fact that changes in (or the termination of) the Framework Agreement are possible only by consensus leads to permanent improvements. In other words, only efficient changes will be implemented. The option of bargaining between the parties is possible, so if one suffers a potential loss, the others can offer to pay compensation. The distribution of a rising (common) wealth to the parties by realising an efficient change is part of the bargaining process; here strategies of extortion seem possible. Compared to the first level, there is no improvement in content on the second level, and no guarantee of finding a better solution than on the party-level. The second level, the Sava Commission, does not promise to find a consensus more easily, but it can lower transaction costs if the members of the commission are experts who have more information than the members, predominantly politicians, of the first level. This can lead to results more quickly than on the first level. Speaking in terms of Game-Theory, the problem of trans-boundary environmental problems constitutes a prisoner's dilemma. If it is impossible for the parties involved to find a solution via bargaining. Only a mutually accepted authority, such as the European Union, is able to intervene and help in producing an efficient solution. Since the countries of the Framework Agreement of the Sava River Basin wish to join European Union in a couple of years and the European Union decides autonomously which countries can join it, the European Union is a strong authority. Therefore, the parties should try to prevent their bargaining problems from being left unsolved, especially if they arose from ethnic quarrels.

Currently, the Framework is a good and efficient instrument to avoid trans-boundary problems concerning the Sava River Basin. The examples of the Rhine and the Danube illustrate that such agreements can work and that the Framework Agreement has a good chance of tackling the problem of the trans-boundary common resource of a "river". In the past, agreements like the Framework Agreement of the Sava River Basin often turned out to have been the starting point for the negotiations of more complex issues between countries. Perhaps the Framework Agreement will also create more trust in political relations between formerly hostile parties. This goal is more important than tackling more difficult problems regarding environmental problems in the future. 모 


\section{References:}

Alchian, A. (1977): Economic Forces at Work, Indianapolis 1977.

Barzel, Y. (1985): "Transaction Costs: Are they Just Costs?", Zeitschrift für die gesamte Staatswissenschaft 141: 4-16.

Coase, R. H. (1960): „The Problem of Social Cost", Journal of Law and Economics 3: 1-44.

Demsetz, H. (1964): "The Exchange and Enforcement of Property Rights", Journal of Law an Economics 7: 11-26.

Demsetz, H. (1967): "Toward a Theory of Property Rights", American Economic Review 57: 347-359.

Hoppe, H. H. (1989): "Fallacies of the Public Goods Theory and the Production of Security", Journal of Libertarian Studies IX: 27-45.

Iza, A: "International Water Governance", Environmental Law Programme, http://www.iucn.org/themes/law/pdfdocuments/EPLP55EN.pdf

[Accessed 22.03.06]

Friedman, D. (1989): The Machinery of Freedom, 2nd Ed., Open Court: La Salle, 1989.

Goodstein, E. S. (2005): Economics and the Environment, John Wiley \& Sons.

Holzinger, K. (2003): “Transnationale Gemeinschaftsgüter: Strategische Konstellationen, Kollektivhandlungsprobleme und Mehrebenensteuerung", Tätigkeitsbericht 2003, Max-Planck-Gesellschaft zur Erforschung von Gemeinschaftsgütern, http://www.mpg.de [Accessed 22.03.06].

Holbrooke, R. (1998): „To End a War“, Random House.

Issar, A. and Brown, N., eds. (2004): Climate Change - Environment and Civilization in the

Middle East, Kluwer Academic Publishers.

OCHA: "Situation Report No. 2, Chemical Spill, People's Republic of China/Russian Federation", http://www. ochaonline.un.org

[Accessed 24.02.06].

Posner, R. (1977): Economic Analysis of Law, Boston 1977.

Robson A.R.W. and Skaperdas, S. (2001): "Costly Enforcement of Property Rights and the Coase Theorem", CESifo Working Paper, No. 762, August 2002.
REGIONAL ENVIRONMENTAL CENTER: "Framework Agreement of the Sava River Basin", http://www.rec.org/REC/Programs/sava/pdf/BackgroundPaper.pdf

[Accessed 22.03.06].

UNEP: "Protected Areas and World Heritage”,

http://www.unep-wcmc.org,

[Accessed 19.02.06].

UNESCO: "Sharing Water- Defining a Common Interest",

http://www.unesco.org/water/wwap/wwdr/pdf/chap12. pdf

[Accessed 22.03.06].

URL: http:// www.internationalwaterlaw.org

[Accessed 22.03.06].

URL: http://www.danubecom-intern.org/ENGLISH/SUMMARY.htm

[Accessed 22.03.06].

URL: http://www.iksr.org/index.php?id=295

[Accessed 22.03.06].

URL: http://www.stabiltiypact.org

[Accessed 22.03.06].

URL: http://untreaty.un.org/ilc/texts/instruments/english/ conventions/8_3_1997.pdf

[Accessed 22.03.06].

URL: http://www.rec.org/REC/Programs/sava/pdf/BackgroundPaper.pdf

[Accessed 27.02.08]. 